\title{
Circulating tumor cells: silent predictors of metastasis
}

\section{[version 1; peer review: 2 approved]}

\author{
LanLan Zhou, David T. Dicker, Elizabeth Matthew, Wafik S. El-Deiry, \\ R. Katherine Alpaugh \\ Fox Chase Cancer Center, Philadelphia, PA, USA
}

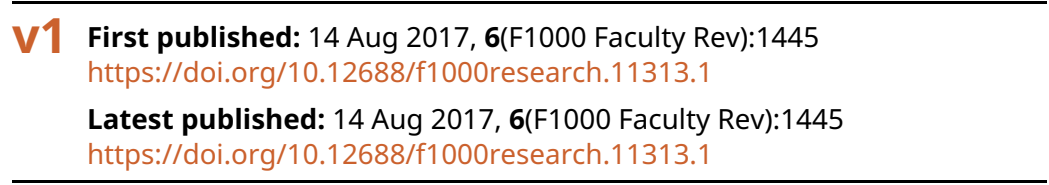

\section{Abstract}

Circulating tumor cells (CTCS) were added to the arsenal of clinical testing in 2004 for three cancer types: metastatic breast, prostate, and colorectal cancer. CTCs were found to be an independent prognostic indicator of survival for these three diseases. Multiple enrichment/isolation strategies have been developed and numerous assay applications have been performed using both single and pooled captured/enriched CTCs. We have reviewed the isolation techniques and touched on many analyses. The true utility of a CTC is that it acts as a "silent" predictor of metastatic disease. The mere presence of a single CTC is an indication that disease has spread from the primary site. Comments and suggestions have been set forth for CTCS and cellfree DNA to be used as a screening panel for the early detection of disease recurrence and metastatic spread, providing the opportunity for early intervention with curative intent to treat metastatic disease.

\section{Keywords}

CTC, Circulating Tumour Cells, Isolation Technique, Immunophenotyping, Oncology

\section{Open Peer Review \\ Approval Status \\ 1 2 \\ version 1 \\ 14 Aug 2017 \\ Faculty Reviews are review articles written by the prestigious Members of Faculty Opinions. The articles are commissioned and peer reviewed before publication to ensure that the final, published version is comprehensive and accessible. The reviewers who approved the final version are listed with their names and affiliations.}

1. Leon W. M. M. Terstappen, University of Twente, Hallenweg 23, 7522 NH Enschede, The Netherlands

\section{Sunitha Nagrath, University of Michigan,}

Ann Arbor, USA

Any comments on the article can be found at the end of the article. 
Corresponding author: R. Katherine Alpaugh (R.Alpaugh@fccc.edu)

Competing interests: The authors declare that they have no competing interests.

Grant information: The authors declare that their work was supported in part by the National Institutes of Health grant R21 CA181419 (PI: El-Deiry) "Immunophenotyping of circulating tumor cells".

The funders had no role in study design, data collection and analysis, decision to publish, or preparation of the manuscript.

Copyright: @ 2017 Zhou L et al. This is an open access article distributed under the terms of the Creative Commons Attribution License, which permits unrestricted use, distribution, and reproduction in any medium, provided the original work is properly cited.

How to cite this article: Zhou L, Dicker DT, Matthew E et al. Circulating tumor cells: silent predictors of metastasis [version 1; peer review: 2 approved] F1000Research 2017, 6(F1000 Faculty Rev):1445 https://doi.org/10.12688/f1000research.11313.1

First published: 14 Aug 2017, 6(F1000 Faculty Rev):1445 https://doi.org/10.12688/f1000research.11313.1 


\section{Introduction}

The description of circulating tumor cells (CTCs) in the peripheral blood of cancer patients dates back to Ashworth's observations in $1869^{1}$. The isolation and detection of CTCs in the blood has proven to be technically challenging. CTCs are rare compared to other circulating cells ${ }^{2}$, and there is a lack of unique, welldefined universal surface targets amongst all malignant cell types. To complicate the issue, there is the possibility of a change in surface targets dependent on CTC maturation status, e.g. during epithelial to mesenchymal transition $(\mathrm{EMT})^{3}$. In spite of these challenges, researchers have developed a variety of techniques to capture and identify these cells. CellSearch ${ }^{\mathrm{TM}}$ (Menarini, Bologna, Italy) is generally thought of as the "gold standard" and remains the only analytically valid and FDA-cleared platform for prognostic use in breast, prostate, and colorectal cancers. Studies by Allard, Cristofanilli, de Bono, and Cohen established enumeration of CTCs as an independent prognostic factor for survival ${ }^{4-11}$. In addition, it has been shown that serial evaluations of CTCs during treatments show fluctuations and can serve as a biomarker of response to monitor therapies ${ }^{12-16}$. However, even though physicians do not treat patients based on the presence of CTCs, there is utility in these cells. CTCs have been labeled as a "liquid biopsy", a source of tumor cells from the blood when conventional tissue biopsies are not attainable, which can be employed to phenotypically characterize the tumor and as a DNA/RNA source for genomic interrogation.

We will briefly summarize examples of various techniques to obtain CTCs and then review the analyses of CTCs. In conclusion, we will comment on CTCs as a "silent predictor".

\section{Isolation techniques}

Isolation strategies can fall into two broad categories: 1) immunobased capture/depletion that relies on immunological recognition of unique biomarkers (i.e. EpCAM) and 2) techniques that exploit a physical property of the CTCs. Although these various techniques are utilized for the enrichment of CTCs, the classification of the captured cells as epithelial cancer cells relies on immuno-staining to confirm whether the isolated cells are tumor or normal circulating cellular components.

\section{Immuno-based capture/depletion for enrichment and/or} immuno-labeling for identification

CellSearch $^{\mathrm{TM}}$ enriches for CTCs in whole blood by first labeling with an avidin-biotin anti-EpCAM-ferrofluid complex followed by magnetic capture. CTCs are then differentially stained using DAPI to identify nucleated cells, epithelial structural cytokeratins (CK8, CK18, and CK19), and anti-CD45 to differentiate CTCs from circulating white blood cells (WBCs).

The LiquidBiopsy platform (Cynvenio Biosystems, Westlake Village, CA, USA) enriches for CTCs by initially differentially immuno-staining with a DAPI, CK, anti-CD45, anti-EpCAMbiotin cocktail and then introduces avidin-ferrofluid for magnetic immobilization. CTCs with a CTC/WBC ratio of $1 \%$ or more are analyzed with next-gene sequencing (NGS). The LiquidBiopsy platform isolates circulating cell-free DNA (ccfDNA) from the plasma, DNA from whole blood to evaluate somatic mutations, and CTC-derived DNA (ctcDNA) for each sample ${ }^{17}$.
Several other techniques utilize flow microchips with immobilized EpCAM antibody either on micro-posts ${ }^{16}$ or in a "herringbone" $\operatorname{design}^{18}$

The Epic system (Epic Sciences Inc., San Diego, CA, USA) has no enrichment step other than red blood cell (RBC) lysis. All nucleated cells are deposited on glass slides, which are then differentially immuno-stained, enabling CTC identification ${ }^{19}$.

The AdnaTest (AdnaGen AG, Langenhagen, Germany) uses anti-EpCAM-labeled magnetic beads for CTC capture. CTCs are lysed to yield mRNA, then analyzed by RT-PCR for tumorassociated expression patterns. CTCs are not enumerated ${ }^{20}$.

Saucedo-Zeni et al. have demonstrated the use of a medical wire functionalized with EpCAM antibodies and placed within a peripheral vein to capture CTCs in vivo ${ }^{21}$.

\section{Physical property-based enrichment}

Researchers have taken advantage of the larger size and/or more structurally rigid properties of CTCs to enrich samples. Among these are CellSieve (Creatv MicroTech Inc., Potomac, MD, USA) $)^{22,23}$ and ISET (RareCells Diagnostics, Paris, France) ${ }^{24}$, which use a filter-based membrane with a specific pore size.

Parsortix (ANGLE plc, Guildford, UK) ${ }^{25}$ and FMSA (Pennsylvania State University, Department of Biomedical Engineering, State College, PA, USA) ${ }^{26}$ microfluidic devices not only use size but also depend on the ability of the CTCs to deform in their enrichment strategies. Final identification is again done by immuno-staining.

Density differential centrifugation can be used to separate CTCs and WBCs from RBCs using Ficoll-Paque (Pharmacia Fine Chemicals, Uppsala, Sweden) $)^{27}$. This product can be directly used for molecular interrogation, flow cytometry, or further selection procedures.

The OncoQuick (Greiner Bio-One International GmbH, Germany) system precedes density centrifugation with size-based filtration to isolate $\mathrm{CTCs}^{28}$, employing RT-PCR for detection. AccuCyte (RareCyte, Seattle, WA, USA) combines density centrifugation with immuno-staining and whole-exome sequencing to identify $\mathrm{CTCs}^{29}$.

The unique electrical properties of CTCs are exploited by using a di-electrophoretic (DEP) field flow technology following a preCTC enrichment in the DEPArray (Menarini Silicon Biosystems, Castel Maggiore, Italy) ${ }^{30}$ and ApoStream (ApoCell, Houston, TX, USA) instruments ${ }^{31,32}$.

Dr Huang's lab at Pennsylvania State University demonstrated that an acoustic, on-chip flow cytometer (taSSAW) was able to separate CTCs from blood in flow ${ }^{33}$. Acoustic separation exploits both size and compressibility differences to separate cell types ${ }^{34}$.

\section{Analysis of isolated circulating tumor cells}

CTCs show a wide range of phenotypic and genetic variations dependent on their primary tumor source. CTCs are, therefore, a very attractive source to use for differential diagnoses, 
prognoses, therapeutic target selections, and therapeutic response monitoring.

\section{Immunophenotyping of circulating tumor cells}

Immunophenotyping of CTCs can reveal the biology of tumor origin for patients with "carcinoma of unknown primaries" (CUP). For example, multiplexed immunofluorescence staining of isolated CTCs with CK7, CK8, CK20, thyroid transcription factor 1 (TTF-1), estrogen receptor (ER), or prostate-specific antigen (PSA) could reveal the tissue of origin as the lung, differentiating it from breast, colorectal, and prostate cancer. CTCs provide a non-invasive diagnostic blood test as an adjunct to a tissue biopsy ${ }^{35}$. Individual CTCs, CTC clusters, EMT-CTCs, and cancer-associated macrophage-like cells (CAMLs) all give support for metastatic disease. These observed variations and the immunophenotyping of CTCs have added prognostic value, e.g. the CTC cluster size and number are associated with lower overall survival in patients with breast, pancreatic, or prostate cancer ${ }^{36,37}$. CAMLs express epithelial, monocytic, and endothelial protein markers and represent engulfed CTCs. The significance of CAMLs to prognosis has not been defined; however, CAMLs may be evidence of early disease when identified in otherwise healthy individuals, thus serving as a screening tool ${ }^{23,38}$. The limitation of conventional immunophenotyping of CTCs is their rarity. In order to analyze multiple biomarkers in a single CTC, techniques have been developed using borohydride quenching on photoactivatable fluorophores of fluorescently stained CTCs, enabling "sequential re-staining" with additional biomarkers without the destruction of epitopes. Up to 10 markers have been shown to be feasible with re-stainings on a single $\mathrm{CTC}^{39}$.

Immunohistochemical staining of matched primary tumor biopsies/cytology specimens shows striking morphological similarity between groups of cells within tumor and circulating tumor microemboli (CTM) from patients with non-small cell lung cancer $(\mathrm{NSCLC})^{40}$. Multiparameter flow cytometric and immunocytochemical analyses can detect, enumerate, and characterize $\mathrm{CTCs}^{41}$. The detection of CTCs in whole blood using flow cytometry indicates metastatic tumor and has been used to monitor treatment effectiveness and disease prognosis ${ }^{42}$. Multicolor flow cytometry allows detailed characterization by determining the expression of markers such as epidermal growth factor receptor (EGFR) and phosphorylated EGFR in $\mathrm{CTCs}^{43}$.

Like solid tumor masses, CTCs are also heterogeneous. Capturing and examining both single CTCs and pools or clusters of CTCs can aid in the stratification of patients based on multiple parameters. Cell cycle staging could give another level of prognosis, and the identification of mitotic CTCs has been correlated with shortened overall survival ${ }^{44}$.

Fluorescence in situ hybridization (FISH) is superior to protein assessment of HER-2 status in predicting response to HER-2-targeted immunotherapy in breast cancer patients, potentially identifying patients who may benefit from treatment adjustments $^{45}$. When FISH HER-2 on CTCs was compared to HER-2 status on the primary tumors, a 93\% concordance in HER-2 status was observed ${ }^{46}$.
Genotyping of circulating tumor cells versus solid tumor CTCs represent the dividing cells within the solid tumor mass, and single-cell sequencing has begun to unravel key questions in cancer invasion, metastasis, and therapy resistance that have been difficult to address with bulk tumor measurement ${ }^{47}$. CTC mutations represent predictive and prognostic biomarkers and identify potential therapeutic targets.

Investigating whether the DNA mutational status of CTCs can represent that of the originating tumor is of great clinical importance. The mutational status of KRAS, BRAF, CD133, and Plastin3 (PLS3) was probed in CTCs from patients with colorectal cancer and was compared with that of the originating tumor from the same patient. Discordance between the original tumor and CTCs for KRAS, BRAF, CD133 rs3130, CD133 rs2286455, and PLS3 rs6643869 mutations was $5.77 \%, 3.85 \%, 11.54 \%, 7.69 \%$, and $11.54 \%$, respectively. This study supports the notion that the DNA mutational status of CTCs is a non-invasive, specific biomarker diagnostic tool ${ }^{48}$.

CTCs enriched by CellSearch have been isolated by DEPArray to obtain single or pooled pure CTCs. Cell lysis yields pure tumor DNA and RNA. Whole-genome or whole-transcriptome amplification can be employed to analyze CTCs for tumor-specific mutations. CTCs of prostate cancer patients have been used to analyze somatic single-nucleotide variants." Census-based sequencing" combining multiple single CTC libraries markedly reduced the false-positive rate of somatic single-nucleotide variants ${ }^{49,50}$. NGS of CTC genomes has also identified distinct copy-number aberrations in patients with chemo-sensitive and chemo-refractory small-cell lung cancer (SCLC) ${ }^{51}$. In additional studies, NGS analysis of single, pooled, and clusters of CTCs from six patients with metastatic breast cancer (MBC) revealed mutational heterogeneity in PIK3CA, TP53, RB1, and ERBB2 genes, mutations matching those revealed in tissue NGS. In six single CTCs isolated from one MBC patient, one CTC had TP53 R110 delC, one CTC had TP53 $\mathrm{R} 110$ delG, and four single CTCs had the wild-type p53. Only a TP53 R110 delC was obtained from 14 pooled CTCs isolated from the same patient. In the tumor breast tissue from the same patient, only TP53 R110 delG mutation was detected. Single CTC and cluster analysis from another MBC patient showed mutational heterogeneity in TP53, PIK3CA, and two ERBB2 mutations ${ }^{52-54}$. Such heterogeneity could be one explanation for the lack of response to targeted therapies.

Additional functional analyses of circulating tumor cells Viable CTCs would allow functional studies on the biology of CTCs, the identification of druggable therapeutic targets or pathways, and in vitro and in vivo drug testing. Analyses reported include direct single-cell lipido-metabolomics of CTCs from a neuroblastoma patient's blood analyzed with live single-cell mass spectrometry ${ }^{55}$; in addition, microtubule bundling used as a marker of efficient taxane drug-target engagement has been visualized in CTCs isolated from castrate-resistant prostate cancer patients receiving taxane chemotherapy with docetaxel and paclitaxel, which has allowed the ex vivo examination of how sensitive CTCs are to taxane therapy. In one experiment, testing revealed an unperturbed microtubule network following docetaxel treatment; however, the addition of 
paclitaxel resulted in microtubule bundling, revealing a sensitivity to that $\mathrm{drug}^{56}$, cell invasion assays using CTCs from ovarian cancer patients have been shown to be predictive of shorter disease-free survival ${ }^{57}$, and epithelial immunospot (EPISPOT) assays have shown the capability of detecting proteins secreted/ released/shed from single CTCs to distinguish between apoptotic and viable $\mathrm{CTCs}^{58}$.

\section{Culture of circulating tumor cells}

Culturing CTCs in vitro/in vivo could facilitate drug development. Owing to the rarity of CTCs, it is necessary to culture CTCs and establish cell lines. Most isolated CTCs are not capable of dividing in situ. However, viable CTCs have been shown to proliferate in cell culture in response to stem cell growth factors such as epidermal growth factor (EGF) and fibroblast growth factor 2 (FGF2). The first permanent cell line came from CTCs of a patient with colon cancer: CTC-MCC-41 $1^{59}$. CTCs isolated from 14 of 19 early stage lung cancer patients have been successfully expanded with a microfluidic in situ capture and grown in a three-dimensional co-culture model. These CTCs were verified to carry identical mutations from the primary tumors ${ }^{60}$. Viable CTCs have also been isolated from the blood of a patient with CUP using a microfluidic flexible micro spring array (FMSA) device $^{61}$.

\section{Circulating tumor-cell-derived xenografts}

The histological, transcriptomic, proteomic, and genomic similarities and comparable treatment responses between the originating tumors and patient-derived xenografts (PDXs) make PDXs useful models in research ${ }^{62}$. CTC-derived xenografts (CDXs) are alternatives to PDXs when tumors are inaccessible or difficult to biopsy. CDXs from patients with either chemo-sensitive or chemorefractory SCLC have been shown to recapitulate the drugsensitivity patterns, genotyping, and clinical outcomes ${ }^{63}$, and combinational treatment was shown to suppress tumor growth in a CDX from a chemo-refractory SCLC patient ${ }^{64}$. Other CDX models have been cited.

\section{Comments and questions}

What have we learned about CTCs? If a CTC or multiple CTCs are present then the cancer is metastatic by definition-it has traveled from its primary source. CTCs serve as a "silent" predictor of metastatic disease, and this is probably the most underutilized but informative usage of CTCs overall. But all cancers are not equal in their ability to present as a CTC. In a disease-to-disease comparison when reviewing the percentage of patients exhibiting CTCs, CTCs are seen in a higher percentage of breast and prostate cancer patients than in colorectal cancer patients ${ }^{4}$. Pancreatic ${ }^{65}$ and ovarian cancers, regardless of their stage and aggressiveness, rarely reveal CTCs. The tissue source of a cancer can influence the likelihood of those cancerous cells entering the circulation. The physiologic and morphologic differences between various organs could predetermine a CTC's ability to enter the circulation. In addition, some cells are more structurally "sound" than others and can withstand the forces in the circulatory system, while others will fragment. The vascularization within various tumors is not equal. The existence and type of lymphatic tissue, organized nodes versus diffuse lymphatic tissue found throughout the gastrointestinal tract or lungs, could greatly influence a tumor's metastatic potential. These are all areas which require further investigation to uncover differences in CTC presence/absence in various cancers.

The continued research in the field of CTCs has shown these cells to be a valuable tumor source: "a liquid biopsy". And because the body is always in a "cleaning mode" with the flux of lymphatic fluid over and through the tissues depositing waste into the blood circulation for disposal, that waste is the supplier of CTCs along with "cell-free circulating plasma"—also termed "a liquid biopsy" - and cell-free DNA (cfDNA) ${ }^{66-68}$. Do CTCs and cfDNA give the same information? No, cfDNA will present in all malignancies in both primary and metastatic disease once a detectable level is reached. However, cfDNA alone cannot predict progression from primary to metastatic disease. cfDNA can be used to detect minimal residual disease following initial treatment for curative intent (chemotherapy/surgery) and to detect recurrence ${ }^{69}$. However, recurrence at the primary site or the spread to metastatic sites cannot be differentiated by cfDNA alone. An increase in cfDNA would be reflective of tumor burden but not where the tumor is, if it cannot be visualized on a scan.

Can CTCs and cfDNA be combined in such a manner to aid in the cure of metastatic disease? Yes, and used in combination and including a control of whole blood to detect somatic mutations, CTCs - the "silent" predictor of metastatic disease-and cfDNA can serve to monitor the progression of primary disease to a metastatic state and this combination can be used for every tumor type $^{66-71}$. Collection algorithms for plasma and CTC determinations can be created with the first screening performed prior to any initial treatment. If CTCs are found (even a CTC level of 1), this is indicative of metastatic disease. Following curative treatment, cfDNA analysis should be employed to determine if there is residual disease and then continue cfDNA testing as surveillance. When increases are seen, the addition of CTCs to cfDNA can be made. cfDNA and CTCs will present significantly earlier than recurrent tumor visibility seen by CT/MRI scans. The advantages of CTCs and cfDNA include 1. they are a cost effective alternative to repeat negative scans, 2. they provide biological information to identify targetable mutations, and 3. they are superior to the routine cancer biomarkers currently followed ${ }^{70,71}$. Clinical trials need to be conducted to validate CTC/cfDNA evaluations following primary disease curative strategies with treatment induction again at the time of CTC/cfDNA emergence to determine overall survival elongations.

\section{Competing interests}

The authors declare that they have no competing interests.

\section{Grant information}

The authors declare that their work was supported in part by the National Institutes of Health grant R21 CA181419 (PI: El-Deiry) "Immunophenotyping of circulating tumor cells".

The funders had no role in study design, data collection and analysis, decision to publish, or preparation of the manuscript.

\section{Acknowledgements}

The authors would like to acknowledge the many dedicated researchers, clinicians and the patients for their time and persistence in showing relevance to CTC testing. 
1. Ashworth $\mathrm{T}$ : A case of cancer in which cells similar to those in tumors were seen in the blood after death. Australian Med J.1869: 14: 146.

2. Alix-Panabières $C$, Pantel $K$ : Circulating tumor cells: liquid biopsy of cancer. Clin Chem. 2013; 59(1): 110-8.

PubMed Abstract | Publisher Full Text

3. Gorges TM, Tinhofer I, Drosch M, et al:: Circulating tumour cells escape from EpCAM-based detection due to epithelial-to-mesenchymal transition. BMC Cancer. 2012; 12: 178.

PubMed Abstract | Publisher Full Text | Free Full Text

4. Allard WJ, Matera J, Miller MC, et al.: Tumor cells circulate in the peripheral blood of all major carcinomas but not in healthy subjects or patients with nonmalignant diseases. Clin Cancer Res. 2004; 10(20): 6897-904. PubMed Abstract | Publisher Full Text

5. Cristofanilli M, Budd GT, Ellis MJ, et al.: Circulating tumor cells, disease progression, and survival in metastatic breast cancer. N Engl J Med. 2004 351(8): 781-91.

PubMed Abstract | Publisher Full Text

6. $\quad \mathrm{F}$ de Bono JS, Scher HI, Montgomery RB, et al:: Circulating tumor cells predict survival benefit from treatment in metastatic castration-resistant prostate cancer. Clin Cancer Res. 2008; 14(19): 6302-9.

PubMed Abstract | Publisher Full Text | F1000 Recommendation

7. Cohen SJ, Alpaugh RK, Gross S, et al:: Isolation and characterization of circulating tumor cells in patients with metastatic colorectal cancer. Clin Colorectal Cancer. 2006; 6(2): 125-32.

PubMed Abstract | Publisher Full Tex

8. Adams DL, Stefansson S, Haudenschild C, et al.: Cytometric characterization of circulating tumor cells captured by microfiltration and their correlation to the CellSearch ${ }^{\circledast}$ CTC test. Cytometry A. 2015; 87(2): 137-44. PubMed Abstract | Publisher Full Text

9. Li P, Stratton ZS, Dao M, et al: Probing circulating tumor cells in microfluidics. Lab Chip. 2013; 13(4): 602-9.

PubMed Abstract | Publisher Full Text | Free Full Text

10. Harouaka R, Kang Z, Zheng SY, et al:: Circulating tumor cells: advances in isolation and analysis, and challenges for clinical applications. Pharmacol Ther. 2014; 141(2): 209-21.

PubMed Abstract | Publisher Full Text | Free Full Text

11. Toss $\mathrm{A}, \mathrm{Mu} Z$, Fernandez $\mathrm{S}$, et al:: СTC enumeration and characterization: moving toward personalized medicine. Ann Transl Med. 2014; 2(11): 108. PubMed Abstract | Publisher Full Text | Free Full Text

12. F Gorin MA, Verdone JE, van der Toom E, et al.: Circulating tumour cells as ( $90-7$.

PubMed Abstract | Publisher Full Text | F1000 Recommendation

13. Hayes DF, Cristofanilli M, Budd GT, et al:: Circulating tumor cells at each followup time point during therapy of metastatic breast cancer patients predict progression-free and overall survival. Clin Cancer Res. 2006; 12 (14 Pt 1): 4218-24.

PubMed Abstract | Publisher Full Text

14. Cohen SJ, Punt CJ, lannotti N, et al.: Relationship of circulating tumor cells to tumor response, progression-free survival, and overall survival in patients with metastatic colorectal cancer. J Clin Oncol. 2008; 26(19): 3213-21. PubMed Abstract | Publisher Full Text

15. Danila DC, Heller G, Gignac GA, et al.: Circulating tumor cell number and prognosis in progressive castration-resistant prostate cancer. Clin Cancer Res. 2007: 13(23): 7053-8. PubMed Abstract | Publisher Full Tex

16. F Nagrath $\mathrm{S}$, Sequist LV, Maheswaran $\mathrm{S}$, et al.: Isolation of rare circulating tumour cells in cancer patients by microchip technology. Nature. 2007; 450(7173): 1235-9.

PubMed Abstract | Publisher Full Text | Free Full Text | F1000 Recommendation

17. Winer-Jones JP, Vahidi B, Arquilevich N, et al.: Circulating tumor cells: clinically relevant molecular access based on a novel CTC flow cell. PLOS One. 2014; 9(1): e86717.

PubMed Abstract | Publisher Full Text | Free Full Text

18. Stott SL, Hsu CH, Tsukrov DI, et al:: Isolation of circulating tumor cells using a microvortex-generating herringbone-chip. Proc Natl Acad Sci U S A. 2010; 107(43): 18392-7.

PubMed Abstract | Publisher Full Text | Free Full Text

19. Werner SL, Graf RP, Landers M, et al:: Analytical Validation and Capabilities of the Epic CTC Platform: Enrichment-Free Circulating Tumour Cell Detection and Characterization. J Circ Biomark. 2015; 4. Publisher Full Text

20. Andreopoulou E, Urbauer D, Krishnamurthy S, et al.: Comparison of circulating tumor cells (CTCs) in metastatic breast cancer (MBC): AdnaTest breast cancer for detection and biological characterization. Clin Cancer Res. 2008; 14(19). Reference Source

21. Saucedo-Zeni $\mathrm{N}$, Mewes $\mathrm{S}$, Niestroj $\mathrm{R}$, et al.: A novel method for the in vivo isolation of circulating tumor cells from peripheral blood of cancer patients using a functionalized and structured medical wire. Int J Oncol. 2012; 41(4): $1241-50$.

PubMed Abstract | Publisher Full Text | Free Full Text

22. Adams DL, Zhu P, Makarova OV, et al.: The systematic study of circulating tumor cell isolation using lithographic microfilters. RSC Adv. 2014; 9: 4334-42. PubMed Abstract | Publisher Full Text | Free Full Text

23. Adams DL, Martin SS, Alpaugh RK, et al.: Circulating giant macrophages as a potential biomarker of solid tumors. Proc Natl Acad Sci U S A. 2014; 111(9): $3514-9$.

PubMed Abstract | Publisher Full Text | Free Full Text

24. Vona G, Sabile A, Louha M, et al.: Isolation by size of epithelial tumor cells : a new method for the immunomorphological and molecular characterization of circulatingtumor cells. Am J Pathol. 2000; 156(1): 57-63. PubMed Abstract | Publisher Full Text | Free Full Text

25. F Hvichia GE, Parveen Z, Wagner C, et al:: A novel microfluidic platform for size and deformability based separation and the subsequent molecular characterization of viable circulating tumor cells. Int J Cancer. 2016; 138(12): 2894-904.

PubMed Abstract | Publisher Full Text | Free Full Text | F1000 Recommendation

26. Harouaka RA, Zhou MD, Yeh YT, et al.: Flexible micro spring array device for high-throughput enrichment of viable circulating tumor cells. Clin Chem. 2014; 60(2): 323-33

PubMed Abstract | Publisher Full Text

27. Weitz $\mathrm{J}$, Kienle $\mathrm{P}$, Lacroix $\mathrm{J}$, et al:: Dissemination of tumor cells in patients undergoing surgery for colorectal cancer. Clin Cancer Res. 1998; 4(2): 343-8. PubMed Abstract

28. Rosenberg R, Gertler R, Friederichs J, et al.: Comparison of two density gradient centrifugation systems for the enrichment of disseminated tumor cells in blood. Cytometry. 2002; 49(4): 150-8.

PubMed Abstract | Publisher Full Text

29. F Campton DE, Ramirez AB, Nordberg JJ, et al.: High-recovery visual dentification and single-cell retrieval of circulating tumor cells for genomic analysis using a dual-technology platform integrated with automated immunofluorescence staining. BMC Cancer. 2015; 15: 360. PubMed Abstract | Publisher Full Text | Free Full Text | F1000 Recommendation

30. F Fabbri F, Carloni S, Zoli W, et al:: Detection and recovery of circulating colon cancer cells using a dielectrophoresis-based device: KRAS mutation status in pure CTCs. Cancer Lett. 2013; 335(1): 225-31. PubMed Abstract | Publisher Full Text | F1000 Recommendation

31. Becker FF, Wang $X$, Huang $Y$, et al.: The removal of human leukaemia cells from blood using interdigitated microelectrodes. J Phys D: Appl Phys. 1994; 27(12): 2659-62.

Publisher Full Text

32. Becker FF, Wang XB, Huang $Y$, et al.: Separation of human breast cancer cells from blood by differential dielectric affinity. Proc Natl Acad Sci U S A. 1995; 92(3): 860-4.

PubMed Abstract | Publisher Full Text | Free Full Text

33. Li P, Mao Z, Peng Z, et al:: Acoustic separation of circulating tumor cells. Proc Natl Acad Sci U S A. 2015; 112(16): 4970-5. PubMed Abstract | Publisher Full Text | Free Full Text

34. Ding $X$, Peng $Z$, Lin SC, et al.: Cell separation using tilted-angle standing surface acoustic waves. Proc Natl Acad Sci U S A. 2014; 111(36): 12992-7. PubMed Abstract | Publisher Full Text | Free Full Text

35. Matthew EM, Zhou L, Yang Z, et al:: A multiplexed marker-based algorithm for diagnosis of carcinoma of unknown primary using circulating tumor cells. Oncotarget. 2016; 7(4): 3662-76.

PubMed Abstract | Publisher Full Text | Free Full Text

36. F Wang C, Mu Z, Chervoneva I, et al.: Longitudinally collected CTCs and CTCclusters and clinical outcomes of metastatic breast cancer. Breast Cancer Res Treat. 2017; 161(1): 83-94.

PubMed Abstract | Publisher Full Text | F1000 Recommendation

37. F Fabisiewicz A, Grzybowska E: CTC clusters in cancer progression and metastasis. Med Oncol. 2017; 34(1): 12. PubMed Abstract | Publisher Full Text | F1000 Recommendation

38. Adams DL, Adams DK, Alpaugh RK, et al:: Circulating Cancer-Associated Macrophage-Like Cells Differentiate Malignant Breast Cancer and Benign Breast Conditions. Cancer Epidemiol Biomarkers Prev. 2016; 25(7): 1037-42. PubMed Abstract | Publisher Full Text | Free Full Text

39. Adams DL, Alpaugh RK, Tsai S, et al:: Multi-Phenotypic subtyping of circulating tumor cells using sequential fluorescent quenching and restaining. Sci Rep. 2016; 6: 33488.

PubMed Abstract | Publisher Full Text | Free Full Text

40. Krebs MG, Hou JM, Sloane R, et al:: Analysis of circulating tumor cells in patients with non-small cell lung cancer using epithelial marker-dependent and -independent approaches. J Thorac Oncol. 2012; 7(2): 306-15. PubMed Abstract 
41. Racila E, Euhus D, Weiss AJ, et al.: Detection and characterization of carcinoma cells in the blood. Proc Natl Acad Sci U S A. 1998; 95(8): 4589-94. PubMed Abstract | Publisher Full Text | Free Full Text

42. Hwu D, Boutrus S, Greiner C, et al:: Assessment of the role of circulating breast cancer cells in tumor formation and metastatic potential using in vivo flow cytometry. J Biomed Opt. 2011; 16(4): 40501. PubMed Abstract | Publisher Full Text

43. Hristozova $\mathrm{T}$, Konschak R, Budach $\mathrm{V}$, et al.: A simple multicolor flow cytometry protocol for detection and molecular characterization of circulating tumor cells in epithelial cancers. Cytometry A. 2012; 81(6): 489-95. PubMed Abstract | Publisher Full Text

44. Adams DL, Adams DK, Stefansson S, et al.: Mitosis in circulating tumor cells stratifies highly aggressive breast carcinomas. Breast Cancer Res. 2016; 18(1): 44 .

PubMed Abstract | Publisher Full Text | Free Full Text

45. F Frithiof H, Aaltonen K, Rydén L: A FISH-based method for assessment of HER-2 amplification status in breast cancer circulating tumor cells following CellSearch isolation. Onco Targets Ther. 2016; 9: 7095-103.

PubMed Abstract | Publisher Full Text | Free Full Text | F1000 Recommendation

46. Mayer JA, Pham T, Wong KL, et al.: FISH-based determination of HER2 status in circulating tumor cells isolated with the microfluidic CEE'M platform. Cancer Genet. 2011; 204(11): 589-95.

PubMed Abstract | Publisher Full Tex

47. F Navin NE: The first five years of single-cell cancer genomics and beyond. Genome Res. 2015; 25(10): 1499-507.

PubMed Abstract | Publisher Full Text | Free Full Text | F1000 Recommendation

48. F Lyberopoulou A, Aravantinos G, Efstathopoulos EP, et al.: Mutational analysis of circulating tumor cells from colorectal cancer patients and correlation with primary tumor tissue. PLoS One. 2015; 10(4): e0123902.

PubMed Abstract | Publisher Full Text | Free Full Text | F1000 Recommendation

49. Speicher MR, Pantel K: Tumor signatures in the blood. Nat Biotechnol. 2014 32(5): 441-3.

PubMed Abstract | Publisher Full Text

50. Lohr JG, Adalsteinsson VA, Cibulskis K, et al.: Whole-exome sequencing of circulating tumor cells provides a window into metastatic prostate cancer. Nat Biotechnol. 2014; 32(5): 479-84.

PubMed Abstract | Publisher Full Text | Free Full Text

51. F Carter L, Rothwell DG, Mesquita B, et al.: Molecular analysis of circulating tumor cells identifies distinct copy-number profiles in patients with chemosensitive and chemorefractory small-cell lung cancer. Nat Med. 2017; 23(1): 114-9.

PubMed Abstract | Publisher Full Text | F1000 Recommendation

52. F Shaw JA, Guttery DS, Hills A, et al:: Mutation Analysis of Cell-Free DNA and Single Circulating Tumor Cells in Metastatic Breast Cancer Patients with High Circulating Tumor Cell Counts. Clin Cancer Res. 2017; 23(1): 88-96. PubMed Abstract | Publisher Full Text | F1000 Recommendation

53. Fernandez SV, Bingham C, Fittipaldi P, et al.: TP53 mutations detected in circulating tumor cells present in the blood of metastatic triple negative breast cancer patients. Breast Cancer Res. 2014; 16(5): 445. PubMed Abstract | Publisher Full Text | Free Full Text

54. Bingham C, Fernandez SV, Fittipaldi $P$, et al:: Mutational studies on single circulating tumor cells isolated from the blood of inflammatory breast cance patients. Breast Cancer Res Treat. 2017; 163(2): 219-30. PubMed Abstract | Publisher Full Text | Free Full Text

55. F Hiyama E, Ali A, Amer S, et al:: Direct Lipido-Metabolomics of Single Floating Cells for Analysis of Circulating Tumor Cells by Live Single-cell Mass Spectrometry. Anal Sci. 2015; 31(12): 1215-7.

PubMed Abstract | Publisher Full Text | F1000 Recommendation

56. Kirby BJ, Jodari M, Loftus MS, et al.: Functional characterization of circulating tumor cells with a prostate-cancer-specific microfluidic device. PLOS One. 2012; 7(4): e35976.

PubMed Abstract | Publisher Full Text | Free Full Text

57. Fan $\mathrm{T}$, Zhao Q, Chen JJ, et al.: Clinical significance of circulating tumor cells detected by an invasion assay in peripheral blood of patients with ovarian cancer. Gynecol Oncol. 2009; 112(1): 185-91.

PubMed Abstract | Publisher Full Text | Free Full Text

58. Alix-Panabières C: EPISPOT assay: detection of viable DTCs/CTCs in solid tumor patients. Recent Results Cancer Res. 2012; 195: 69-76. PubMed Abstract | Publisher Full Tex

59. F Cayrefourcq L, Mazard T, Joosse S, et al:: Establishment and characterization of a cell line from human circulating colon cancer cells. Cancer Res. 2015; 75(5): 892-901.

PubMed Abstract | Publisher Full Text | F1000 Recommendation

60. Zhang Z, Shiratsuchi $\mathrm{H}$, Lin J, et al:: Expansion of CTCs from early stage lung cancer patients using a microfluidic co-culture model. Oncotarget. 2014; 5(23): 12383-97.

PubMed Abstract | Publisher Full Text | Free Full Text

61. Gallant JN, Matthew $\mathrm{EM}$, Cheng $\mathrm{H}$, et al:: Predicting therapy response in live tumor cells isolated with the flexible micro spring array device. Cell Cycle. 2013; 12(13): 2132-43.

PubMed Abstract | Publisher Full Text | Free Full Text

62. $\mathrm{F}$ Aparicio $\mathrm{S}$, Hidalgo $\mathrm{M}, \mathrm{Kung} \mathrm{AL}$ : Examining the utility of patient-derived xenograft mouse models. Nat Rev Cancer. 2015; 15(5): 311-6. PubMed Abstract | Publisher Full Text | F1000 Recommendation

63. $\mathrm{F}$ Hodgkinson CL, Morrow CJ, Li Y, et al.: Tumorigenicity and genetic profiling of circulating tumor cells in small-cell lung cancer. Nat Med. 2014; 20(8): 897-903.

PubMed Abstract | Publisher Full Text | F1000 Recommendation

64. F Potter DS, Galvin M, Brown S, et al:: Inhibition of PI3K/BMX Cell Survival Pathway Sensitizes to BH3 Mimetics in SCLC. Mol Cancer Ther. 2016; 15(6): $1248-60$

PubMed Abstract | Publisher Full Text | F1000 Recommendation

65. Dotan E, Alpaugh RK, Ruth K, et al:: Prognostic Significance of MUC-1 in Circulating Tumor Cells in Patients With Metastatic Pancreatic Adenocarcinoma. Pancreas. 2016; 45(8): 1131-5

PubMed Abstract | Publisher Full Text | Free Full Text

66. Haber DA, Velculescu VE: Blood-based analyses of cancer: circulating tumor cells and circulating tumor DNA. Cancer Discov. 2014; 4(6): 650-61. PubMed Abstract | Publisher Full Text | Free Full Text

67. F Ignatiadis M, Lee M, Jeffrey SS: Circulating Tumor Cells and Circulating Tumor DNA: Challenges and Opportunities on the Path to Clinical Utility. Clin Cancer Res. 2015; 21(21): 4786-800.

PubMed Abstract | Publisher Full Text | F1000 Recommendation

68. F Alix-Panabières C, Pantel K: Clinical Applications of Circulating Tumor Cells and Circulating Tumor DNA as Liquid Biopsy. Cancer Discov. 2016; 6(5): 479-91. PubMed Abstract | Publisher Full Text | F1000 Recommendation

69. F Tie J, Wang Y, Tomasetti C, et al: Circulating tumor DNA analysis detects minimal residual disease and predicts recurrence in patients with stage II colon cancer. Sci Transl Med. 2016; 8(346): 346ra92.

PubMed Abstract | Publisher Full Text | Free Full Text | F1000 Recommendation

70. Danila DC, Fleisher M, Scher HI: Circulating tumor cells as biomarkers in prostate cancer. Clin Cancer Res. 2011; 17(12): 3903-12. PubMed Abstract | Publisher Full Text | Free Full Text

71. Tan CR, Zhou L, El-Deiry WS: Circulating Tumor Cells Versus Circulating Tumor DNA in Colorectal Cancer: Pros and Cons. Curr Colorectal Cancer Rep. 2016; 12(3): 151-61.

PubMed Abstract | Publisher Full Text | Free Full Tex 


\section{Open Peer Review}

\section{Current Peer Review Status:}

\section{Editorial Note on the Review Process}

Faculty Reviews are review articles written by the prestigious Members of Faculty Opinions. The articles are commissioned and peer reviewed before publication to ensure that the final, published version is comprehensive and accessible. The reviewers who approved the final version are listed with their names and affiliations.

\section{The reviewers who approved this article are:}

\section{Version 1}

\section{Sunitha Nagrath}

Department of Chemical Engineering, University of Michigan, Ann Arbor, USA

Competing Interests: No competing interests were disclosed.

\section{Leon W. M. M. Terstappen}

Department of Medical Cell BioPhysics, University of Twente, Hallenweg 23, $7522 \mathrm{NH}$ Enschede, The Netherlands

Competing Interests: No competing interests were disclosed.

The benefits of publishing with F1000Research:

- Your article is published within days, with no editorial bias

- You can publish traditional articles, null/negative results, case reports, data notes and more

- The peer review process is transparent and collaborative

- Your article is indexed in PubMed after passing peer review

- Dedicated customer support at every stage

For pre-submission enquiries, contact research@f1000.com 